УДК 547.913:543.544.3:543.51

\title{
ИЗУЧЕНИЕ КОМПОНЕНТНОГО СОСТАВА ЛЕТУЧИХ ВЕЩЕСТВ БАГУЛЬНИКА БОЛОТНОГО МЕТОДОМ ТЕРМОДЕСОРБЦИОННОЙ ГАЗОВОЙ ХРОМАТО-МАСС-СПЕКТРОМЕТРИИ
}

\author{
() Н.В. Ульяновский ${ }^{1,2}$, Д.С. Косяков ${ }^{1 *}$, С.А. Покрышкин ${ }^{1}$, К.Г. Боголицын ${ }^{1,2}$, О.С. Ульяновская ${ }^{3}$ \\ ${ }^{1}$ Северный (Арктический) фредеральный университет имени \\ М.В. Ломоносова, ул. Набережная Северной Двины, 17, Архангельск, 163002 \\ (Россия), e-mail: kosyakov@mail.ru \\ ${ }^{2}$ Институт экологических проблем Севера УрО РАН, ул. Набережная \\ Северной Двины, 23, Архангельск, 163000 (Россия) \\ ${ }^{3}$ Северный государственный медицинский университет, Троицкий пр., 51, \\ Архангельск, 163000 (Россия)
}

Работа посвящена исследованию состава эфирного масла багульника болотного (Ledum palustre L.), произрастающего на Европейском Севере Российской Федерации и широко используемого в официальной и народной медицине. С этой целью предложено использование метода термодесорбционной газовой хромато-масс-спектрометрии, позволяющего проводить определение летучих соединений непосредственно в биологических тканях без предварительного извлечения, а также осуществлять локальный анализ различных частей растения. Изучено влияние температуры на качественный и количественный состав летучих соединений, выделяемых при нагревании растительной ткани. Показано сходство в составах эфирного масла, полученного методом гидродистилляции, и фракций летучих соединений, извлекаемых путем термодесорбции при температурах $50-100{ }^{\circ} \mathrm{C}$. Установлено преобладание в составе эфирного масла Ledum palustre L. палюстрола, ледола, некоторых других сесквитерпеноидов, монотерпеноидов ипсдиенола и амитинола а также ряда фурановых монотерпеноидов, что позволяет отнести исследуемое растение к неизвестному ранее хемотипу. сорбция.

Ключевые слова: багульник болотный, эфирное масло, газовая хроматография, масс-спектрометрия, термоде-

Работа выполнена с использованием оборудования ЦКП НО «Арктика» Северного (Арктического) федерального университета имени М.В. Ломоносова при финансовой поддержке Министерства образования и науки РФ. Авторы выражают благодарность за финансовую поддержку Российскому фонду фундаментальных исследований (проект № 13-03-12238 офи_м).

Ульяновский Николай Валерьевич - младший научный сотрудник Центра коллективного пользования научным оборудованием «Арктика», e-mail: uluanovskii_n@mail.ru

Косяков Дмитрий Сергеевич - директор Центра коллективного пользования научным оборудованием «Арктика», кандидат химических наук, доцент, e-mail:kosyakov@mail.ru

Покрышкин Сергей Александрович - младший научный сотрудник Центра коллективного пользования научным оборудованием «Арктика»,

e-mail: serge.physchem@yandex.ru

Боголицын Константин Григорьевич - директор, доктор химических наук, профессор,

e-mail: k.bogolitsin@narfu.ru

Ульяновская Ольга Сергеевна - студент,

e-mail: ulyanovskaya_o@mail.ru

\section{Введение}

Багульник болотный на протяжении столетий широко используется в народной медицине для лечения заболеваний органов дыхания, желудочнокишечного тракта, кожных заболеваний, а также в качестве анальгетика [1]. Современная фармакология не только не отказалась от применения этого растения, но и позволила получить новые данные о биологической активности содержащихся в нем компонентов, особенно их антидиабетическом, противораковом и антиоксидантном действии [2, 3].

Наибольшую ценность представляет эфирное масло багульника, содержащее несколько десятков

\footnotetext{
* Автор, с которым следует вести переписку.
} 
компонентов, среди которых преобладают моно- и сесквитерпеноиды. Среди них выделяется сесквитерпеноид ледол, содержание которого в масле в определенных условиях может достигать 41\% [4]. К компонентам эфирного масла нетерпеновой природы относятся различные ароматические соединения (главным образом фенолы), жирные кислоты, алифатические углеводороды, спирты и альдегиды.

Различными исследователями неоднократно отмечалась исключительно высокая вариабельность химического состава эфирного масла Ledum palustre L., набор компонентов в котором, а также их соотношение, определяются не только частью растения [5], из которой извлекалось масло, но также временем сбора и, в первую очередь, регионом произрастания растения [4, 6-9]. Это связывается с существованием внутри вида множества хемотипов, возникновение которых обусловлено конкретными эколого-географическими условиями в ареалах распространения багульника. Так, по данным работы [4], на территории Российской Федерации можно выделить четыре основных хемотипа. Первый характеризуется преобладанием терпенов ряда $n$-ментана и макрокомпонента лимонена (южные районы Томской обл., Курильские о-ва), второй хемотип с преобладанием мирцена и соединений гидроазуленового ряда (центральные районы Европейской территории РФ, северо-восток Томской обл., Хабаровский край), третий хемотип - наличием сабинена и других бициклических монотерпенов (Забайкалье), четвертый хемотип - с доминированием терпиненов и их производных - n-цимена и аскаридола (Восточная Сибирь, Камчатка, Амурская обл.).

К сожалению, в литературе отсутствуют достоверные данные о составе эфирного масла Ledum palustre L., произрастающего в условиях приарктического климата на Европейском Севере России несмотря на крайне широкую распространенность багульника болотного в этом регионе.

В настоящее время основным методом изучения химического состава эфирных масел растений является газовая хроматография с масс-селективным детектированием [10], дающая возможность эффективного разделения сложных смесей летучих соединений на капиллярных колонках и идентификации компонентов по их масс-спектрам с использованием обширных коммерчески доступных баз данных.

Наиболее слабым звеном используемых аналитических методик является подготовка проб, т.е. предварительное извлечение эфирного масла из тканей растения. Широко применяемые методы отгонки с водяным паром и гидродистилляции [11] позволяют выделять нерастворимые в воде компоненты в достаточно мягких условиях, тем не менее и в этом случае возможно протекание побочных процессов окисления и гидролиза некоторых соединений, в результате чего полученные препараты могут заметно отличаться по составу от исходных эфирных масел, содержащихся в растительных тканях. Другим недостатком методов, основанных на предварительной отгонке, является довольно большой объем растительного сырья, необходимый для выделения представительной пробы эфирного масла с минимальными потерями. Это затрудняет проведение локального анализа летучих фракций, содержащихся в разных частях растения.

На наш взгляд, интересной альтернативой исследованию предварительно выделенного эфирного масла является применение метода термодесорбционной хромато-масс-спектрометрии, в котором анализу подвергаются фракции, переходящие в газовую фазу непосредственно из растительного материала при нагревании до различных температур. Поскольку процесс проходит в атмосфере высокочистого гелия без использования органических растворителей пробы или воды как среды для отгонки эфирного масла, процессы гидролиза и окисления компонентов сводятся к минимуму, а состав летучих фракций должен быть максимально приближен к естественному. Ранее [12] данный метод успешно применялся нами для исследования продуктов деградации экотоксикантов в почвах.

В связи с этим целями настоящего исследования являются изучение компонентного состава эфирного масла багульника болотного, произрастающего в субарктической зоне Европейского Севера РФ, а также оценка возможности применения термодесорбции для хромато-масс-спектрометрического анализа эфирных масел непосредственно в тканях растений на примере Ledum palustre L.

\section{Экспериментальная часть}

В качестве объекта исследования выбран Багульник болотный (Ledum palustre L.), собранный в Шенкурском районе Архангельской области в июне 2013 г. Свежее растительное сырье было высушено при комнатной температуре. Образец сохранялся в плотных полиэтиленовых пакетах в темноте. Непосредственно перед проведением анализа листья отделялись от стеблей и измельчались.

Для извлечения эфирного масла методом гидродистилляции [13] навеска образца массой 1,00 г помещалась в перегонную колбу объемом 50 мл и заливалась 20 мл деионизованной воды. Смесь подверга- 
лась перегонке в течение 2 ч, в результате чего в приемном сосуде собиралось около 15 мл отгона. Эфирное масло извлекалось путем добавления к отгону 2 мл смеси гексана с диэтиловым эфиром (1:1) с последующим перемешиванием, центрифугированием для разделения слоев и отделением органического слоя. 1 мкл полученного раствора эфирного масла вводился в газовый хромато-масс-спектрометр при помощи автосамплера.

В экспериментах с использованием термодесорбции образцы дополнительно измельчались и усреднялись путем кратковременного растирания в ступке с хлоридом калия (1:5), после чего навеска массой 30 мг (содержащая 5 мг растительного материала) переносилась в пустую стеклянную сорбционную трубку и фиксировалась в ней при помощи пробок из деактивированной минеральной ваты. Сорбционная трубка помещалась в термодесорбер и подвергалась ступенчатому нагреву в токе гелия до температур 50, 100, 150 и 200 C. На каждой температурной ступени выделяющиеся летучие соединения подвергались криофокусированию в ловушке с полимерным сорбентом Теnax ТА и вводились в газохроматографическую колонку.

Хромато-масс-спектрометрический анализ проводился с использованием газового хромато-массспектрометра GCMS-QP2010 Plus (Shimadzu, Япония), оснащенного термодесорбционной системой TD-20. При исследовании эфирного масла, полученного методом гидродистилляции, термодесорбционная система ввода образца заменялась на автосамплер АОС-20і. Для разделения использовалась капиллярная колонка HP-5MS 60 м×0,32 мм (Agilent, США).

Условия хроматографического разделения: газ-носитель - гелий (марка 6.0), скорость потока 2 мл/мин, деление потока $100: 1$. Температурная программа термостата колонок: 0 мин $-50{ }^{\circ} \mathrm{C}$, подъем до $300{ }^{\circ} \mathrm{C}\left(5 \mathrm{~K} /\right.$ мин), выдерживание при $300{ }^{\circ} \mathrm{C}$ в течение 10 мин. Общее время анализа 60 мин.

Детектирование осуществлялось с помощью квадрупольного масс-детектора в режиме сканирования в диапазоне масс от 20 до $600 \mathrm{~m} / \mathrm{z}$. Тип ионизации - электронный удар (70 эВ). Температура ионного источника и интерфейса $-230{ }^{\circ} \mathrm{C}$, напряжение на детекторе - 0,7 кВ. Идентификацию компонентов проводили с использованием библиотек масс-спектров NIST-08 и Wiley-9. Компоненты, для которых степень совпадения масс-спектра с библиотечным составляла менее $80 \%$, считались неидентифицированными. Дополнительным параметром, принимаемым во внимание при идентификации соединений с близкими спектрами, служила величина индекса удерживания.

\section{Обсуждение результатов}

Хроматограмма эфирного масла листьев Ledum palustre L., полученного методом гидродистилляции, представлена на рисунке 1. Результаты обработки хромато-масс-спектрометрических данных приведены в таблице 1.

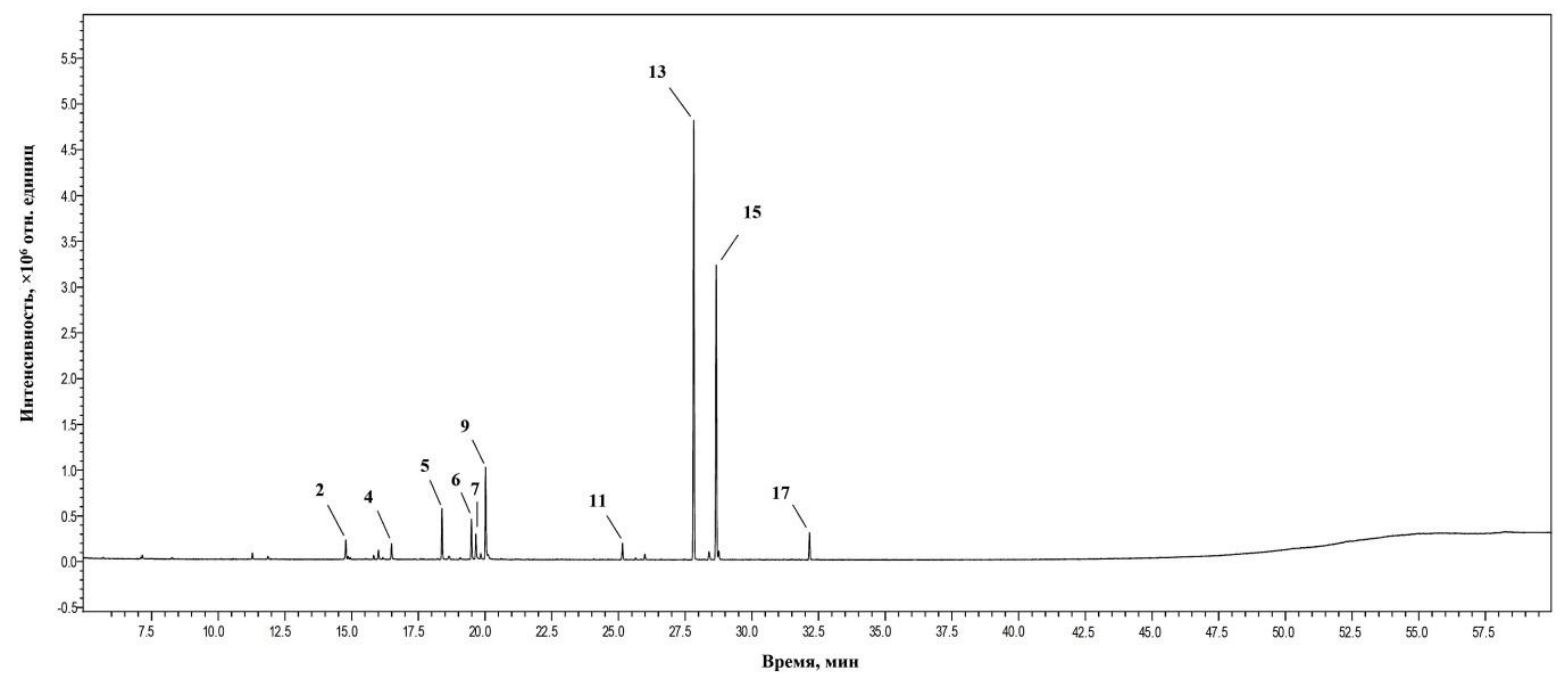

Рис. 1. Хроматограмма по полному ионному току эфирного масла листьев Багульника болотного, полученного методом гидродистилляции. Обозначения пиков соответствуют номерам компонентов в таблице 1. 
Таблица 1. Компоненты эфирного масла листьев Ledum palustre L., полученного методом гидродистиляции

\begin{tabular}{|c|c|c|c|c|}
\hline № & $\begin{array}{c}\mathrm{t}_{\mathrm{R}} \\
\text { мин }\end{array}$ & Соединение & $\begin{array}{c}\text { Степень соответствия } \\
\text { библиотечному масс- } \\
\text { спектру, \% }\end{array}$ & $\begin{array}{c}\text { Относительная } \\
\text { площадь пика, \% }\end{array}$ \\
\hline 1 & 11,25 & $\beta$-пинен & 96 & 0,49 \\
\hline 2 & 14,75 & 2-метил-6-метилен-3,7-октадиен-2-ол (амитинол) & 87 & 1,72 \\
\hline 3 & 15,98 & $\beta$-мирцен & 88 & 0,73 \\
\hline 4 & 16,47 & Лимонен оксид & 86 & 1,24 \\
\hline 5 & 18,36 & 2-метил-5-(3-фурил)-3-пентен-2-ол & 85 & 4,24 \\
\hline 6 & 19,46 & Лепалон & 83 & 3,28 \\
\hline 7 & 19,63 & Ипсдиенол & 86 & 2,22 \\
\hline 8 & 19,82 & $\alpha$-оцимен & 84 & 0,45 \\
\hline 9 & 19,99 & Лепалол & 88 & 8,14 \\
\hline 10 & 20,09 & 1,1-диметил-2-(2,4-пентадиенил)-циклопропан & 85 & 0,45 \\
\hline 11 & 24,94 & Аллоаромаденрен & 95 & 1,41 \\
\hline 12 & 25,76 & Леден & 96 & 0,46 \\
\hline 13 & 27,80 & Палюстрол & 94 & 41,08 \\
\hline 14 & 28,37 & Веридифлорол & 92 & 0,97 \\
\hline 15 & 28,64 & Ледол & 94 & 27,49 \\
\hline 16 & 28,73 & $\beta$-оплопенон & 84 & 0,81 \\
\hline 17 & 32,37 & Валеренал & 85 & 2,38 \\
\hline- & - & Неидентифицированные компоненты & $<80$ & 2,46 \\
\hline
\end{tabular}

Неидентифицированными остались соединения, имеющие пики площадью не более $0,4 \%$ и соответственно крайне низкую интенсивность масс-спектров, не позволяющую достичь требуемой достоверности результатов библиотечного поиска.

Очевидно, что для летучих веществ исследованного образца багульника характерно доминирование двух компонентов - сесквитерпеноидов ряда аромадендрана - ледола и палюстрола, составляющих более двух третей массы эфирного масла. Кроме данных соединений, обнаружено еще пятнадцать веществ, на долю которых приходится 97,5\% общей площади пиков на хроматограмме. Среди них в наибольших концентрациях присутствуют еще один представитель аромадендранового ряда - аллоаромадендрен, сесквитерпеноид валереналь, монотерпеноиды ипсдиенол и амитинол, а также фурановые монотерпеноиды лепалол, лепалон и 2-метил-5-(3-фурил)-3-пентен-2-ол (рис. 2). Последние три соединения составляют около $15 \%$ образца, что весьма необычно для багульников, произрастающих на территории России, и напоминает данные, полученные авторами исследования [7] для эфирного масла Ledum palustre L., собранного в осенний период на территории Литвы. Сочетание большого содержания ледола и палюстрола, а также беспрецедентно высоких концентраций фурановых монотерпеноидов, с незначительной долей мирцена и соединений ментанового ряда, позволяет предполагать, что багульник, произрастающий в приарктической зоне Европы, может быть отнесен к отдельному, пятому хемотипу данного растения, встречающемуся на территории Российской Федерации.

Хроматограммы летучих соединений листьев багульника болотного, зарегистрированные с использованием термодесорбции аналитов непосредственно из тканей растения при температурах $50-100{ }^{\circ} \mathrm{C}$ (рис. 3), в целом согласуются с хроматограммой эфирного масла, полученного методом гидродистилляции - времена удерживания компонентов остаются неизменными, а преобладающими являются пики ледола и палюстрола. Начиная с температуры $150^{\circ} \mathrm{C}$ вид хроматограммы меняется (рис. Зв), появляется набор доминирующих пиков высококипящих компонентов, к которым относятся высшие алифатические углеводороды и спирты. При температуре $200{ }^{\circ} \mathrm{C}$ такие компоненты наряду с продуктами разрушения полисахаридов и, в какой-то степени, лигнинных веществ составляют основу хроматограммы, а количества обнаруживаемых терпеноидов становятся незначительными.

Для идентификации продуктов, извлекаемых при термодесорбции, были выбраны хроматографические пики, площадь которых превышает $0,4 \%$ от общей площади всех пиков по крайней мере на одной из хроматограмм, полученных при разных температурах десорбции. Выбор такого критерия позволил охватить не менее 95\% компонентного состава извлекаемых летучих веществ. Площади пиков подвергались нормализации, при этом за $100 \%$ принималась суммарная площадь всех пиков в исследуемом диапазоне температур $\left(50-200{ }^{\circ} \mathrm{C}\right)$. Результаты проведенных расчетов представлены в таблице 2. 
<smiles>C=C1CC[C@@H]2[C@H]([C@@H]3CC[C@@H](C)[C@H]13)C2(C)C</smiles>

I<smiles>C=C(C)C(O)CCc1ccoc1</smiles>

IV<smiles>C[C@H]1CCC2C([C@]3(C)CC[C@H](C)[C@H]3O)[C@@H]21</smiles>

II

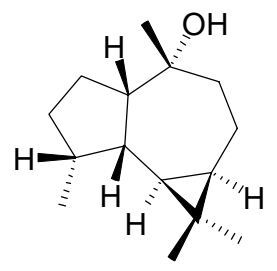

III

Рис. 2. Структурные формулы основных компонентов эфирного масла багульника болотного, полученного методом гидродистилляции<smiles>CC(C)(O)/C=C/Cc1ccoc1</smiles><smiles>C=C(C)C(=O)CCc1ccoc1</smiles>

VI

V<smiles>CC1=C2[C@@H](/C=C(\C)C=O)CC[C@@H](C)[C@]2(C)CC1</smiles>

VII<smiles>C=CC(=C)C[C@H](O)C=C(C)C</smiles>

VIII

Сравнение данных таблиц 1 и 2 позволяет говорить об очевидном сходстве составов летучих фракций, получаемых методами гидродистилляции и термодесорбции при температурах 50-100 들 по двум доминирующим компонентам. Так, содержание ледола и палюстрола в суммарной фракции, выделенной в термодесорбере при указанных температурах, составляет 34 и 44\% соответственно, в то время как концентрации, найденные в отгоне, равнялись соответственно 27 и 41\%. Число компонентов, выделяемых при термодесорбции в мягких условиях, также сопоставимо с данными таблицы $1-$ при $50{ }^{\circ} \mathrm{C}$ оно, как и в случае гидродистилляции, составляет 17 , а при подъеме температуры до $100{ }^{\circ} \mathrm{C}$ добавляется еще девять соединений. Помимо двух основных компонентов преобладают валереналь, аллоаромадендрен, $\alpha$-гвайен, леден и лепалон. Различия в содержании и номенклатуре компонентов могут быть связаны с возможностью протекания в ходе гидродистилляции побочных процессов [14], связанных с гидролизом, изомеризацией и окислением лабильных соединений, а также заметной растворимостью части компонентов в воде и соответственно неполным их переходом в анализируемый органический слой. Нельзя исключать и вероятности каталитической трансформации некоторых компонентов эфирных масел в условиях термодесорбции за счет контакта при повышенных температурах с металлическими поверхностями линий, соединяющих сорбционную трубку с криоловушкой и газовым хроматографом. В качестве основного отличия результатов, полученных методом термодесорбционной хромато-масс-спектрометрии, можно назвать относительно малое найденное содержание фурановых монотерпеноидов. Доля лепалона составляет порядка 1-2\%, в то время как лепалол и 2-метил-5-(3-фурил)-3пентен-2-ол вообще не были обнаружены. В целом термодесорбционный метод позволяет обнаружить значительно большее количество соединений, содержащихся в листьях багульника, общее число которых для всех температурных ступеней десорбции составило 50.

Сопоставление эффективности извлечения летучих соединений из растительного сырья с использованием гидродистилляционного и термодесорбционного методов проведено путем сравнения абсолютных площадей хроматографических пиков для основных компонентов, нормированных на единицу массы исходного сырья. Полученные результаты демонстрируют существенно большие выходы эфирного масла в случае термодесорбции аналитов непосредственно из твердой фазы. Например, для ледола отношение суммы площадей пиков при температурах десорбции 50-150 드 к площади пика для гидродистиллята составило 1,37, а для палюстрола - 1,18. 
Таблица 2. Компоненты, идентифицируемые при термодесорбции образца в зависимости от температуры.

\begin{tabular}{|c|c|c|c|c|c|c|c|c|}
\hline \multirow{2}{*}{ № } & \multirow{2}{*}{$\begin{array}{l}\mathrm{t}_{\mathrm{R}} \\
\text { мин }\end{array}$} & \multirow{2}{*}{ Соединение } & \multirow{2}{*}{$\begin{array}{c}\text { Степень } \\
\text { соответствия } \\
\text { библиотечному } \\
\text { масс-спектру, \% }\end{array}$} & \multicolumn{5}{|c|}{$\begin{array}{c}\text { Относительная площадь пика, \%, при } \\
\text { температуре десорбции }\end{array}$} \\
\hline & & & & $50{ }^{\circ} \mathrm{C}$ & $100{ }^{\circ} \mathrm{C}$ & $150{ }^{\circ} \mathrm{C}$ & $200{ }^{\circ} \mathrm{C}$ & Итого \\
\hline 1 & 3,42 & Ацетон & 96 & - & 0,07 & 0,14 & 0,25 & 0,46 \\
\hline 2 & 3,67 & Уксусная кислота & 89 & - & 0,05 & 0,15 & 1,22 & 1,42 \\
\hline 3 & 4,24 & 1-гидрокси- 2-пропанон & 97 & - & - & - & 0,27 & 0,27 \\
\hline 4 & 6,71 & 2-фуранкарбоксальдегид & 98 & - & - & - & 0,48 & 0,48 \\
\hline 5 & 7,19 & 3-гексен-1-ол & 94 & 0,03 & 0,03 & 0,11 & 0,41 & 0,57 \\
\hline 6 & 7,93 & (+)-2',3'-дидеоксирибонолактон & 81 & - & - & - & 0,39 & 0,39 \\
\hline 7 & 10,58 & 1,2,3-бутантриол & 91 & - & - & 0,08 & 0,25 & 0,33 \\
\hline 8 & 15,41 & $\begin{array}{l}\text { 2,3-дигидро-3,5-дигидрокси-6-метил- } \\
\text { 4Н-пирен-4-он, }\end{array}$ & 89 & - & - & 0,05 & 0,64 & 0,68 \\
\hline 9 & 16,04 & Цитидин & 88 & - & - & - & 0,22 & 0,22 \\
\hline 10 & 16,42 & 3,4-дигидрокситетрагидро-2-фуранон & 84 & - & - & - & 0,36 & 0,36 \\
\hline 11 & 17,71 & 1,3-декадиен-7,9-дион & 83 & 0,03 & 0,12 & 0,33 & 0,03 & 0,52 \\
\hline 12 & 17,9 & $\begin{array}{l}\text { 5-(гидроксиметил)-2- } \\
\text { фуранкарбоксальдегид }\end{array}$ & 91 & - & - & - & 0,93 & 0,93 \\
\hline 13 & 18,87 & $\begin{array}{l}\text { 2-(1,1-диметил-2-пропенил)- } \\
\text { бицикло[2.2.1]гептан }\end{array}$ & 82 & 0,04 & 0,13 & 0,27 & - & 0,44 \\
\hline 14 & 19,42 & Лепалон & 81 & 0,08 & 0,33 & 0,37 & - & 0,78 \\
\hline 15 & 20,56 & 4-этинил-2-метокси-фенол & 75 & - & - & - & 0,21 & 0,21 \\
\hline 16 & 22,72 & Борнилацетат & 87 & 0,16 & 0,28 & 0,05 & - & 0,48 \\
\hline 17 & 22,97 & Борнилбромид & 83 & - & 0,19 & 0,01 & - & 0,20 \\
\hline 18 & 24,34 & $\alpha$-гуаен & 92 & 0,44 & 0,01 & 0,02 & 0,02 & 0,49 \\
\hline 19 & 24,51 & Изоледен & 92 & 0,15 & - & - & - & 0,15 \\
\hline 20 & 24,71 & Линалоол & 82 & - & 0,25 & - & - & 0,25 \\
\hline 21 & 24,92 & Аллоаромаденрен & 93 & 0,76 & 0,02 & 0,01 & - & 0,79 \\
\hline 22 & 25,14 & 1,6-ангидро-D-глюкопираноза & 93 & - & - & - & 0,36 & 0,36 \\
\hline 23 & 25,43 & Гермакрен Д & 93 & 0,13 & - & - & - & 0,13 \\
\hline 24 & 25,66 & Дегидроаромадендран & 92 & 0,34 & 0,01 & 0,01 & - & 0,37 \\
\hline 25 & 25,79 & Леден & 94 & 0,31 & 0,02 & 0,02 & 0,03 & 0,38 \\
\hline 26 & 25,99 & Гераниол & 89 & - & 0,22 & 0,03 & - & 0,26 \\
\hline 27 & 26,48 & 8-гидроксилиналол & 87 & - & 0,41 & 0,06 & - & 0,48 \\
\hline 28 & 27,80 & Палюстрол & 91 & 11,41 & 5,15 & 0,21 & - & 16,78 \\
\hline 29 & 28,37 & Веридифлорол & 89 & 0,17 & 0,15 & 0,01 & - & 0,33 \\
\hline 30 & 28,37 & Хинная кислота & 86 & - & - & - & 0,79 & 0,79 \\
\hline 31 & 28,68 & Ледол & 90 & 6,79 & 5,89 & 0,19 & 0,11 & 12,99 \\
\hline 32 & 28,79 & Метил-Д-глюкопиранозид & 83 & - & - & - & 0,22 & 0,22 \\
\hline 33 & 29,38 & $\alpha$-лимонен диэпоксид & 86 & - & 0,11 & - & - & 0,11 \\
\hline 34 & 31,81 & 2,6-диметил-1,7-октадиен-3-ол, & 81 & - & - & 0,11 & - & 0,11 \\
\hline 35 & 32,40 & Валеренал & 86 & 0,59 & 1,82 & 0,07 & 0,03 & 2,51 \\
\hline 36 & 41,61 & Генейкозан & 97 & - & - & - & 0,53 & 0,53 \\
\hline 37 & 46,09 & Докозан & 92 & - & - & 0,15 & - & 0,15 \\
\hline 38 & 47,65 & Ланостерол & 82 & 0,16 & - & 0,02 & - & 0,18 \\
\hline 39 & 47,90 & Тетракосил ацетат & 96 & - & - & 0,10 & 0,09 & 0,19 \\
\hline 40 & 49,26 & 1-гентетраконтанол & 95 & - & 0,03 & 1,86 & 2,31 & 4,20 \\
\hline 41 & 50,78 & Тетракозан & 89 & - & - & 0,13 & 0,18 & 0,30 \\
\hline 42 & 51,43 & Спинацен & 95 & - & - & 0,45 & 0,34 & 0,79 \\
\hline 43 & 51,90 & Стигмаст-4-ен-3-он & 89 & 0,25 & - & - & - & 0,25 \\
\hline 44 & 52,42 & Пентакозан & 94 & - & 0,10 & 5,02 & 7,62 & 12,75 \\
\hline 45 & 53,97 & $\begin{array}{l}\text { 5-гидрокси-7-метокси-2-(4- } \\
\text { метоксифенил)-4Н-1-бензопирен-4-он, }\end{array}$ & 81 & - & - & 0,02 & 0,25 & 0,27 \\
\hline 46 & 54,21 & Дотриаконтан & 96 & - & - & 0,30 & 0,81 & 1,11 \\
\hline 47 & 56,29 & Гексатриаконтан & 96 & - & - & 8,38 & 20,18 & 28,56 \\
\hline 48 & 56,49 & $\begin{array}{l}\text { [6-циклофенил-3-(3-циклопенти- } \\
\text { лпропил) гексил]-циклогексан }\end{array}$ & 80 & - & - & - & 0,47 & 0,47 \\
\hline 49 & 57,66 & $\alpha$-токоферол- $\beta$-Д-маннозид & 94 & - & - & 0,19 & 2,26 & 2,45 \\
\hline 50 & 58,60 & Тетратетраконтан & 96 & - & - & 0,22 & 1,35 & 1,57 \\
\hline \multicolumn{4}{|c|}{ Итого } & 21,84 & 15,40 & 19,12 & 43,63 & 100 \\
\hline
\end{tabular}



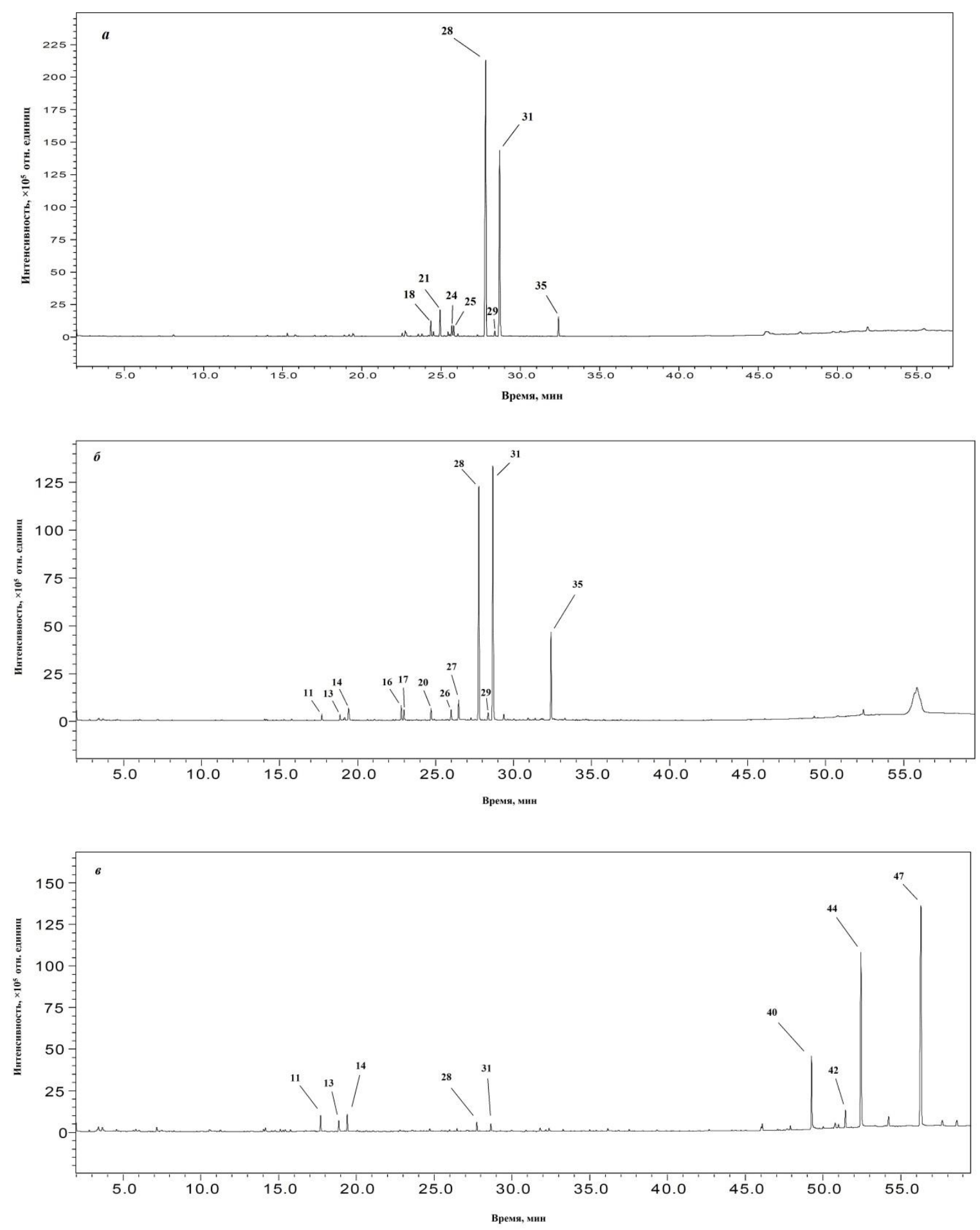

Рис. 3. Хроматограммы по полному ионному току летучих компонентов листьев багульника после термодесорбции при температурах $50^{\circ} \mathrm{C}$ (а), $100{ }^{\circ} \mathrm{C}$ (б) и $150{ }^{\circ} \mathrm{C}$ (в). Обозначения пиков соответствуют номерам компонентов в таблице 2.

Важным преимуществом термодесорбционной хромато-масс-спектрометрии является возможность дополнительного дифференцирования компонентного состава растительных тканей по температурам перехода в газовую фазу. Ступенчатое изменение температуры позволило, с одной стороны, раздельно проанализировать составы легко- и труднолетучих фракций, а с другой стороны, сделать выводы о степени связанности тех или иных соединений в растительной ткани. Возможность использования при термодесорбции повышенных температур $\left(150-200^{\circ} \mathrm{C}\right)$ открывает также перспективы для характеристики компонентного состава и содержания таких соединений, как высшие алифатические углеводороды. В исследуемом образце они пред- 
ставлены преимущественно гексатриаконтаном, пентакозаном, на долю которых приходится до 70\% суммарной площади пиков на хроматограммах компонентов, извлеченных при 150 и $200{ }^{\circ} \mathrm{C}$. Данные компоненты, по-видимому, являются основой кутикулярного воска Ledum palustre L., покрывающего листья и придающего им гидрофобность, а также обеспечивающего защиту от микроорганизмов и насекомых.

Полученные результаты показывают, что термодесорбционный хромато-масс-спектрометрический анализ может быть успешно использован как в качестве дополнения к традиционным методам анализа эфирных масел, так и в качестве самостоятельного метода, позволяющего избегать окислительной и гидролитической деструкции компонентов, проводить локальный анализ с использованием миллиграммовых количеств образца, осуществлять скрининг растительных материалов на содержание летучих соединений.

\section{Bblbodbl}

1. Изучен компонентный состав эфирного масла Багульника болотного, произрастающего на Европейском Севере РФ. Показано преобладание в нем палюстрола, ледола, некоторых других сесквитерпеноидов, монотерпеноидов ипсдиенола и амитинола, а также ряда фурановых монотерпеноидов, что позволяет отнести исследуемое растение к неизвестному ранее хемотипу.

2. Установлено сходство в составах эфирного масла Ledum palustre L., полученного методом гидродистилляции, и фракций летучих соединений, извлекаемых путем термодесорбции при температурах $50-100{ }^{\circ} \mathrm{C}$. Основным отличием результатов, полученных методом термодесорбционной хромато-масс-спектрометрии, является относительно малое найденное содержание фурановых монотерпеноидов.

3. Использование высоких температур десорбции позволяет изучать состав высококипящих фракций летучих соединений, и в частности высших углеводородов, входящих в состав растительных восков.

4. Термодесорбционная хромато-масс-спектрометрия может быть успешно применена для целей локального анализа летучих соединений в различных частях растения, а также быстрого скрининга растительного сырья.

\section{Список литературы}

1. Веретнова О.Ю., Поляков Н.А., Ефремов А.А. Природа экстрактивных веществ багульника болотного, произрастающего в Красноярском крае // Химия растительного сырья. 2007. №2. С. 67-72.

2. Dampc A., Luczkiewicz M. Rhododendron tomentosum (Ledum palustre). A review of traditional use based on current research // Fitoterapia. 2013. Vol. 85. Pp. 130-143.

3. Kim D., Nam B. Extracts and essential oil of Ledum palustre L. leaves and their antioxidant and antimicrobial activities // Journal of food science and nutrition. 2006. Vol. 11. Pp. 100-104.

4. Белоусова Н.И., Хан В.А., Ткачёв А.В. Химический состав эфирного масла багульников // Химия растительного сырья. 1999. №3. С. 5-38.

5. Gretšušnikova T., Järvan K., Orav A., Koel M. Comparative analysis of the composition of the essential oil from the shoots, leaves and stems the wild Ledum palustre L. from Estonia // Procedia Chemistry. 2010. N2. Pp. 168-173

6. Butkiene R., Mockute D. The variability of the essential oil composition of wild Ledum palustre L. shoots during vegetation period // Journal of Essential Oil Research. 2011. Vol. 23:1. Pp. 9-13.

7. Butkienè R., Šakočiūtè V., Latvènaitè D., Mockutè D. Composition of young and aged shoot essential oils of the wild Ledum palustre L. // Chemija. 2008. Vol. 19. N2. Pp. 19-24.

8. Пляшечник M.A. Химический состав эфирного масла Ledum palustre L. (Ericaceae) при увеличении содержания доступного азота в почве криолитозоны (центральная Эвенкия) // Химия растительного сырья. 2012. №2. C. 139-144.

9. Ueyama Y., Hashimoto S., Nii H., Furukawa K. Constituents of the essential oil from Ledum palustre L. var. angustum N. Busch // Nippon Nogeikagaku Kaishi. 1989. Vol. 63. N4. Pp. 849-851.

10. Baser K.H.C., Buchbauer G. Handbook of essential oils: science, technology, and applications. Boca Raton, 2010. 975 p.

11. Cseke L.J., Kirakosyan A., Kaufman P.B., Warber S.L., Duke J.A., Brielmann H.L. Natural Products from Plants. Boca Raton, 2006. 551 p.

12. Ульяновский Н.В., Покрышкин С.А., Косяков Д.С., Кожевников А.Ю., Ивахнов А.Д., Боголицын К.Г. Хромато-масс-спектрометрическая идентификация продуктов трансформации 1,1-диметилгидразина в торфяной почве // Химия растительного сырья. 2012. №3. С. 181-187.

13. European Pharmacopoeia, 3rd Edn. Directorate for the quality of Medicines of the Council of Europe (EDQM). Strasbourg, 1996. Pp. 121-122.

14. Turek C., Stintzing F.C. Stability of Essential Oils: A Review // Comprehensive Reviews in Food Science and Food Safety. 2013. Vol. 12. Pp. 40-53. 
Ul'yanovskii N.V..$^{1,2}$, Kosyakov D.S..$^{{ }^{*}}$, Pokryshkin S.A. ${ }^{l}$, Bogolitsyn K.G. ${ }^{1,2}$, Ul'yanovskaya O.S. ${ }^{3}$ STUDY OF VOLATILE COMPOUNDS COMPOSITION OF LEDUM PALUSTRE L. USING THE METHOD OF THERMODESORPTION GAS CHROMATOGRAPHY - MASS SPECTROMETRY

${ }^{I}$ North (Arctic) Federal University named after M.V. Lomonosov, ul. Northern Dvina Embankment, 17, Arkhangelsk, 163002 (Russia),e-mail: kosyakov@mail.ru

${ }^{2}$ Institute of Ecology of North, Ural Branch of the Russian Academy of Sciences, ul. Northern Dvina Embankment, 23, Arkhangelsk, 163000 (Russia)

${ }^{3}$ Severny State Medical University, Trinity ave., 51, Arkhangelsk, 163000 (Russia)

The composition of essential oil obtained by hydrodistillation from Marsh tea (Ledum palustre L.) is studied. The method of thermodesorption gas chromatography - mass spectrometry is proposed for investigation on volatile compounds in plant tissues without precursive isolation. Effect of temperature on qualitative and quantitative composition of volatile compounds evaporating during the plant tissue heating is demonstrated. The comparison of data obtained by thermodesorption method with the results of hydrodistilled essential oil analysis is done.

Keywords: Ledum palustre L., essential oil, gas chromatography, mass spectrometry, thermodesorption

\section{References}

1. Veretnova O.Ju., Poljakov N.A., Efremov A.A. Himija rastitel'nogo syr'ja, 2007, no. 2, pp. 67-72. (in Russ.).

2. Dampc A., Luczkiewicz M. Fitoterapia, 2013, vol. 85, pp. 130-143.

3. Kim D., Nam B. Journal of food science and nutrition, 2006, vol. 11, pp. 100-104.

4. Belousova N.I., Han V.A., Tkachjov A.V. Himija rastitel'nogo syr'ja, 1999, no. 3, pp. 5-38. (in Russ.).

5. Gretšušnikova T., Järvan K., Orav A., Koel M. Procedia Chemistry, 2010, no. 2, pp. 168-173

6. Butkiene R., Mockute D. Journal of Essential Oil Research, 2011, vol. 23:1, pp. 9-13.

7. Butkienè R., Šakočiūtė V., Latvėnaitė D., Mockutė D. Chemija, 2008, vol. 19, no. 2, pp. 19-24.

8. Pljashechnik M.A. Himija rastitel'nogo syr'ja, 2012, no. 2, pp. 139-144. (in Russ.).

9. Ueyama Y., Hashimoto S., Nii H., Furukawa K. Nippon Nogeikagaku Kaishi, 1989, vol. 63, no. 4, pp. 849-851.

10. Baser K.H.C., Buchbauer G. Handbook of essential oils: science, technology, and applications. Boca Raton, 2010, $975 \mathrm{p}$.

11. Cseke L.J., Kirakosyan A., Kaufman P.B., Warber S.L., Duke J.A., Brielmann H.L. Natural Products from Plants, Boca Raton, 2006, 551 p.

12. Ul'janovskij N.V., Pokryshkin S.A., Kosjakov D.S., Kozhevnikov A.Ju., Ivahnov A.D., Bogolicyn K.G. Himija rastitel'nogo syr'ja, 2012, no. 3, pp. 181-187. (in Russ.).

13. European Pharmacopoeia, 3rd Edn. Directorate for the quality of Medicines of the Council of Europe (EDQM). Strasbourg, 1996, pp. 121-122.

14. Turek C., Stintzing F.C. Comprehensive Reviews in Food Science and Food Safety, 2013, vol. 12, pp. 40-53.

Received November 28, 2013

Revised March 24, 2014

\footnotetext{
* Corresponding author.
} 
